\title{
Pelaksanaan Penanaman Nilai Pendidikan Karakter di SMA Bertalenta INS Kayu Tanam Kabupaten Padang Pariaman
}

\author{
Ripho Delzy Perkasa ${ }^{1 *}$, Nuriza Dora ${ }^{2}$, Cicilia Melinda ${ }^{3}$ \\ ${ }^{1,2}$ UIN Sumatera Utara Medan \\ ${ }^{3}$ Universitas Pasir Pengaraian \\ *Correspondence email: riphodelzyperkasa@uinsu.ac.id.
}

\begin{abstract}
Abstrak. Penelitian bertujuan untuk menqetahui dan menganalisis bagaimana pelaksanaan pendidikan karakter dan factor- factor yang berpengaruh terhadap pelaksanaan pendidikan karakter di SMA INS Kayu Tanam Kabupaten Padang Pariaman. Jenis Penelitian merupakan penelitian kualitatif yang dilaksanakan di SMA INS Kayu Tanam dengan Informan penelitian adalah Kepala Sekolah, Majelis guru sertas siswa atau peserta didik Adapun Teknik pengumpulan data yang digunakan dalam penelitian ini adalah observasi, wawancara dan dokumentasi. Hasil penelitian yang diperoleh dilapangan menunjukkan bahwa:1) Pelaksanaan pendidikan karakter di SMA INS Kayu Tanam sudah dapat dikatan baik dengan cara pembiasaan yang dilakukan oleh siswa selama berada disekolah dan asrama ,2) Adapun Faktor yang mempengaruhi pelaksanaan pendidikan karakter di SMA INS Kayu Tanam dapat dibagi kedalam dua kelompok yaitu: a) Ada yang dikatakan sebagai faktor pendukung yang meliputi komitmen serta kerjasama yang baik dari semua pihak yang berada dilingkungan sekolah baik warga sekolah yang berada didalam lingkungan sekolah maupun pihak yang berada diluar sekolah seperti masyarakat sekitar dilingkungan sekolah, b) Ada yang dikatakan sebagai factor penghambat pelaksanaan pendidikan karakter di sekolah meliputi linqkunqan yang kurang mendukung, kurangnya dana sekolah, kuranqnya komunikasi yang intens antara pihak sekolah dengan orang tua atau wali murid, kurangnya kesadaran dari peserta didik yang dikarenakan belum mampu beradaptasi dengan lingkungan yang baru serta kurangnya pengawasan dari pihak sekolah. Dalam hal ini penulis menyarankan agar pelaksanaan pendidikan karakter melalui pembiasaan di SMA INS Kayu Tanam agar dapat lebih ditingkatkan sehingga tujuan yang diharapkan dari pihak sekolah dengan menyeimbangkan kemampuan otak dengan akhlak dapat terwujud.
\end{abstract}

Kata Kunci: Pendidikan; karakter; SMA; Bertalenta

Abstract. This study aims to find out and analyze how the implementation of character education and the factors that influence the implementation of character education in SMA INS Kayu Tanam, Padang Pariaman Regency. This type of research is a qualitative research conducted at SMA INS Kayu Tanam with the research informants being the principal, the assembly of teachers and students or students. The data collection techniques used in this study were observation, interviews and documentation. The results of the research obtained in the field show that: 1) The implementation of character education at SMA INS Kayu Tanam can be said to be good by means of habituation carried out by students while in school and dormitory, 2) The factors that influence the implementation of character education at SMA INS Kayu Tanam can be divided into two groups, namely: a) There are those who are said to be supporting factors which include commitment and good cooperation from all parties in the school environment, both school residents who are within the school environment and parties outside the school such as the surrounding community in the school environment, $b$. There are what are said to be factors that hinder the implementation of character education in schools including unsupportive links, lack of school funds, lack of intense communication between the school and parents or guardians of students, lack of awareness of students who are rooted in comfort has not been able to adapt to the new environment and the lack of supervision from the school. In this case, the author suggests that the implementation of character education through habituation at SMA INS Kayu Tanam can be further improved so that the expected goals of the school by balancing brain abilities with morals can be realized.

Keywords: Educatins; characters; SMA; talented

\section{PENDAHULUAN}

Pendidikan merupakan bagian dari usaha yang ditempuh oleh manusia dalam rangka memperoleh ilmu yang dijadikan sebagai dasar untuk merubah pengetahuan dari yang tidak tau sama sekali menjadi tau serta merubah perilaku dari yang buruk menjadi perilaku yang lebih baik. Sehingga pendidikan merupakan bagian dari salah satu proses yang membentuk karakter manusia dalam menjalankan kehidupannya .Dalam hal ini sangatlah mustahil seorang individu dapat mencapai derajat manusia seutuhnya tanpa memperoleh pengetahuan dan ilmu lainnya melalui proses pendidikan yang baik. Dalam pelaksanaan proses belajar mengajar di sekolah penanaman nilai-nilai karakter harus terwujud dalam sikap dan perilaku peserta didik sebagai bagian dari proses pendidikan karakter yang meliputi kejujuan (olah hati), kecerdasan (otak), ketangguhan (fisik), dan kepedulian (afektif) (Kementerian Pendidkan 2011). Sejauh ini kenyataan dilapangan telah cukup banyak memperlihatkan kepada kita bukti bahwa kekuatan dan kebesaran suatu bangsa pada hakikatnya berpangkal pada kekuatan karakternya yang menjadi tulang punggung bagi setiap bentuk kemajuan lahiriah bangsa tersebut. Hal ini tentunya sesuai dengan yang sudah 
diamanatkan secara implisit yang kemudian ditegaskan dalam Rencana Pembangunan Jangka Panjang Nasional (RPJPN) tahun 2005-2025, dimana Pemerintah menjadikan pembangunan karakter sebagai salah satu program prioritas pembangunan nasional (Marzuki, 2012)

Pembiasaan itu bukan hanya mengajarkan pengetahuan tentang hal-hal yang benar dan salah, akan tetapi juga mampu merasakan terhadap nilai yang baik dan tidak baik, serta bersedia melakukannya dari lingkup terkecil seperti keluarga sampai dengan cakupan yang lebih luas di masyarakat. Nilai-nilai tersebut perlu ditumbuhkembangkan peserta didik yang pada akhirnya akan menjadi cerminan hidup bangsa Indonesia. Oleh karena itu, sekolah memiliki peranan yang besar dalam pengembangan pendidikan karakter karena peran sekolah sebagai pusat pembudayaan melalui pendekatan pengembangan budaya sekolah (school culture).Dengan kata lain, pendidikan karakter yang baik harus melibatkan pengetahuan yang baik (moral knowing), perasaan yang baik atau loving good (moral feeling) dan perilaku yang baik (moral action) sehingga terbentuk perwujudan kesatuan perilaku dan sikap hidup peserta didik (Marzuki, 2012)

Penerapan Pendidikan karakter melalui pembiasaan sudah seyognya membawa peserta didik ke pengenalan nilai melaui transfer knowledge yang mendukung kecakapan kognitif siswa, penghayatan nilai- nilai yang mengharuskan peserta didik cakap secara afektif, dan pada akhirnya mengimplementasikan serta menampilkan karakter tersebut dalam kehidupan nyata sehari-hari. Ketika ini terwujud maka inilah yang dikatakan sebagai rancangan pendidikan karakter (moral) yang oleh Thomas Lickona disebut moral knowing, moral feeling, dan moral action. Penanaman nilai Karakter yang berkualitas tentunya perlu dibentuk dan dibina sejak dari rumah dan sedini mungkin. Sebagaimana yang kita ketahui usia dini merupakan waktu yang paling tepat untuk mengajarkan kepada anak- anak bagaimana cara bersikap yang baik, penanaman nilai serta pembentukan kepribadian seorang anak.Hal tersebut dapat dilakukan dengan baik karena pada usia tersebut anak lebih cenderung meniru apa yang ditampilkan oleh orang tua mereka dalam kehidupan sehari-hari. Kegagalan orang tua dalam menanamkan nilai karakter dan memberikan contoh kepada anak dirumah tentunya akan berdampak pada kegagalan anak dalam bersikap sehingga berpengaruh dalam pembentukan kepribadian anak. Tentunya pendidikan dalam keluarga nilai strategis dalam pembentukan kepribadian anak. Sejak kecil anak sudah mendapatkan pendidikan dari kedua orang tuanya melalui keteladan dan kebiasaan hidup sehari- hari dalam keluarga (Djamarah, 2004)

Berdasarkan hasil studi pendahuluan yang penulis lakukan, di SMA INS Kayu Tanam Kabupaten Padang Pariaman diperoleh informasi bahwa penanaman nilai pendidikan karakter bukanlah dalam bentuk sebuah mata pelajaran tertentu, namun dilaksanakan melalui pembelajaran yang sudah berjalan di sekolah tersebut baik dilingkungan sekolah maupun dalam semua kegiatan atau aktivitas yang berlangsung di asrama peserta didik. Sebagai sekolah berasrama yang mengusung motto sekolah berasrama bertalenta maka pelaksanaan pendidikan karakter di SMA INS Kayu Tanam ini meliputi: 1) pengintegrasian dalam setiap mata pelajaran, 2) kegiatan pengembangan diri, dan 3) Sebagai lembaga pendidikan SMA INS Kayu Tanam melaksanakan atau menyelenggarakan tiga sekolah umum dalam satu ruang pendidikan asrama seperti Tradisi pesantren, sekolah umum dan sekolah teknik, dimana hingga saat ini masih menjadikan pendidikan keterampilan sebgai watak utama dalam pengembangan watak peserta didiknya. Oleh karena itu SMA INS Kayu Tanam mengahruskan peserta didik memiliki keterampilan dibidang seni, pertanian dan industri. Selain itu, dalam pelaksanaan pendidikan karakter di sekolah tersebut juga di dukung oleh seluruh warga sekolah dengan terlibat ke dalam segala bentuk kegiatan yang terjadi di lingkungan sekolah. Setiap warga sekolahmemiliki peran serta bertanggungjawab dalam pelaksanaan pendidikan karakter itu sendiri.

\section{METODE}

Penelitian dilakukan dengan cara penelitian lapangan (field research) dengan menggunakan data kualitatif. Metode kualitatif sebagai penelitian yang bermaksud untuk memahami fenomena tentang apa yang dialami oleh subjek penelitian, misalnya perilaku, persepsi, motivasi, tindakan, secara holistik dengan cara deskripsi dalam bentuk kata-kata dan bahasa, pada suatu konteks khusus dicirikan oleh tujuan penelitian yang berupaya untuk memahami gejala-gejala yang dituangkan dalam bentuk narasi atau sebuah cerita tanpa ada berhubungan dengan angka-angka atau statistika (Moleong 2010). Dengan penelitian lapangan untuk mengeksplorasi dan mengklarifikasi mengenapenanaman nilai pendidikan karakter di SMA INS Kayu Tanam. Data yang diperoleh nanti akan berupa kata-kata, gambar dan perilaku.

Pengumpalan data dengan cara pengumpulan studi dokumen atau buku-buku bahan bacaan dan wawancara kepada warga sekolah. Wawancara yang dilakukan dengan dua cara, membuat pertanyaan tertulis secara terstruktur dan wawancara tidak terstruktur (bebas) yang dilakukan secara fleksibel untuk menggali informasi lebih dalam lagi. Setelah data terkumpulkan saya nanti akan menuliskan secara utuh penelitian yang saya lakukan.

Dalam penelitian ini penulis mengambil lokasi di SMA INS Kayu Tanam sebagai tempat penelitian.Sebagai subjek dalam penelitian ini adalah kepala sekolah, guru dan siswa. 


\section{HASIL DAN PEMBAHASAN}

\section{Pelaksanaan Pendidikan Karakter di SMA INS Kayu Tanam Kabupaten Padang Pariaman}

Sebagai satuan pendidikan yang menuntut siswanya harus mampu menyeimbangkan antara otak, akhlak dan keterampilan maka SMA INS Kayu Tanam dituntut harus mampu menanamkan nilai pendidikan karakter bagi selmua peserta didiknya tanpa terkecuali. Oleh karena itu, sebagai lembaga pendidikan SMA INS Kayu Tanam juga bertanggung jawab untuk melaksanakan nilai-nilai atau penanaman nilai karakter. Pimpinan beserta pihak sekolah SMA INS Kayu Tanan selalu berupaya agar semua nilai- nilai karakter bangsa yang ada mampu dimiliki oleh siswa yang pada akhirnya tercermin dalam semua perilaku yang ditampilkan oleh peserta didik selama berada dilingkungan sekolah maupun berada diluar sekolah nantinya. Hal ini sesuai dengan apa yang diungkapkan oleh Pimpinan SMA INS Kayu Tanam:

\begin{abstract}
"Hingga saat ini sekolah terus berupaya menjadi wadah atau sarana dalam penanaman nilai karakter untuk semua peserta didik tanpa terkecuali. Memang pada dasarnya Pendidikan Karakter tidak diberikan dalam satu mata pelajaran khusus akan tetapi sekolah menuntut agar semua siswa mampu menyerap dan menerapkan nilai karakter selama berada dilingkungan sekolah maupu berada diluar lingkungan sekolah. Adapun bentuk kongkret dalam penanaman nilai- nilai pendidikan karakter tersebut dapat dilakukan dengan guru dijadikan sebagai pioneer percontohan bagi siswa, selain itu pembiasaan-pembiasaan dalam setiap aktivitas yang dilakukan oleh siswa, serta mengadakan kegiatankegiatan sekolah yang dapat memfasilitasi serta menumbuh kembangkan penanaman nilai pendidikan karakter bagi peserta didik kami." (Kepsek)
\end{abstract}

Lebih lanjut untuk mengetahui bagaimana pelaksanaan penanaman nilai pendidikan karakter di SMA INS Kayu Tanam, kepala sekolah menjelaskan bahwa:

"Penanaman nilai pendidikan Karakter itu akan terlihat atau dapat diwujudkan dalam bentuk pembiasaan yang dilakukan oleh siswa dalam keseharian mereka, sebagai bukti nyata dari perilaku kebiasaan. Tentunya hal tersebut tidak akan terwujud jika penanaman nilai pendidkan karakter diberikan hanya sebatas pada pemberian materi tanpa ada pembiasaan sehingga tujuan akhir dari sekolah yang ingin menyeimbangkan antara tiga kemampuan tidak akan tercapai dengan baik, karena pada dasarnya kita bersama tahu bahwasanya karakter itu menyatu dan akan terbentuk pada masing-masing individu selama mereka berproses dalam kehidupannya." (Kepsek)
Sesuai dengan informasi yang diperoleh melalui wawancara dengan pimpinan SMA INS Kayu Tanam diatas penanaman nilai pendidikan karakter disekolah lebih menitik beratkan pada pembiasaan yang dilakukan oleh peserta didik baik selama berada dilingkungan sekolah maupun berada diluar lingkungan sekolah .Hal ini senada dengan yang diungkapkan oleh "UM" selaku Guru Bidang Studi Pendidikan Agama Islam dan Budi Pekerti. Beliau mengungkapkan bahwa sangat pentingnya pembiasaan penanaman nilai pendidikan karakter bagi peserta didik sebagai wujud dari pelaksanaan pendidikan karakter:

"Benar sekali, dimana peserta didik harus mampu menampilkan sikap melalui pembiasaan yang mengarah kepada penanaman nilai pendidikan karakter selama berada dalam lingkungan sekolah atau pun berada diluar lingkungan sekolah, oleh karena karena menurut saya pembiasaan adalah salah satu cara yang paling tepat dalam penanaman nilai pendidikan karakter di SMA INS Kayu Tanam. Hal tersebut dapat dilihat dari aktivitas mereka mulai dari bangun pagi sampai mereka kembal keasrama untuk tidur. Didalam setiap aktivitas yang mereka lakukan secara tidak langsung sudah menampilkan sikap penanaman nilai karakter tersebut koq, misal nilai karakter kejujuran, dan bekerjasama pada saat mereka shalat, makan bersama diruang makan diasrama atau ketika mereka melaksanakan kegiatan gotong royong dilingkungan asrama atau dilingkungan sekolah." (UM)

Berdasarkan hasil wawancara tersebut, diperoleh informasi bahawa penanaman nilai karakter di SMA INS Kayu Tanam dilaksanakan dengan cara pembiasaan yang dilakukan oleh peserta didik selama berada dilingkungan sekolah maupun berada diluar lingkungan sekolah. Dalam hal ini melalui program atau kegiatan yang telah dirancang oleh pihak sekolah agar bisa memfasilitasi penanaman nilai pendidikan karakter di SMA INS Kayu Tanam serta menjadi identitas atau icon sekolah yang mampu menyeimbangkan antara otak, akhlak dan keterampilan.

Beradasarkan temuan penulis dilapangan terkait penanaman nilai pendidikan karakter di SMA INS Kayu Tanam masih ditemukan beberapa kekurangan dalam penanaman nilai pendidikan karakter di SMA INS Kayu Tanam antara lain:

\section{Nilai karakter religius}

Pada penanaman nilai pendidikan karakter religious masih banyak ditemukan para siswa yang belum memiliki kesadaran untuk sholat dengan kemauan sendiri dengan kata lain siswa masih harus dipaksa untuk melaksanakan shalat berjamaah di setiap waktu shalat. Sehingga guru harus melakukan piket secara bergantian 
untuk mengawasi siswa agar ikut sholat serta memberikan teguran dan sanksi bagi peserta didik yang tidak mentaati aturan yang sudah ditetapkan oleh pihak sekolah. Hal ini terlihat dari pengamatan yang dilakukan penulis dilapangan dimana guru piket memeriksa setiap kelas dan mencari siswa yang tidak melaksanakan sholat berjamaah di waktu zuhur. Masih banyak diantara siswa yang masih berada di ruang kelas walaupun sudah tiba waktu sholat. Kemudian guru mencatat serta memberikan teguran dan sanksi bagi siswa tidak ikut sholat bersama misalnya harus membersihkan kamar mandi mesjid, membersihkan halaman mesjid setelah sekolah berakhir. Hal tersebut diungkapkan oleh "UM"selaku guru Bid Studi PAI dan Budi Pekerti:

"Ya beginilah kondisi disini dimana siswa masih harus "ditokok dulu baru mau Shalat", masih ada diantara siswa kami yang belum memiliki kesadaran dari dalam diri sendiri untuk melaksanakan Shalat. Masih ada diantara siswa ketika waktu Shalat dating main kucing- kucingan dengan guru, tidak jarang kami menemukan siswa yang masih berada didalam kelas ketika Shalat berjamah dilaksanakan di mesjid. Bagi siswa yang ketahuan tidak melaksanakan Shalat berjamaah akan dicatat namanya dan akan dimasukkan kedalam buku kasus sekolah." (UM)

\section{Nilai karakter kejujuran}

Hal paling sederhana yang sering terjadi disekolah yang bertentangan dengan penanaman nilai pendidikan karakter di SMA INS Kayu Tanam adalah perilaku menyontek atau mencenek pada saat pelaksanaan Kuis, Ulangan Harian maupun Ulangan Umum. Masih banyak diantara siswa yang ketauan menyontek ketika ujian berlangsung, modus mereka beragam mulai dari membuat kertas contekan atau jimat, membagi jawaban pada saat ujian, menggunakan HP atau pergi ke WC sekolah untuk melihat catatan atau sejenisnya. Selain itu masih banyak diantra siswa yang tidak menyerahkan uang SPP kesekolah setelah diberikan oleh orang tua mereka, sehingganya pada saat akan ujian banyak diantara siswa yang belum mampu melunasi kewajiban mereka sehingga tidak diizinkan untuk mengikuti ujian sampai mereka melaunasi keawajiban mereka kepada pihak sekolah. Hal tersebut sesuai diungkapkan oleh Pimpinan SMA INS Kayu Tanam:

"Memang benar tidak semua siswa memiliki sikap yang jujur, sangat sulit untuk membangun sikap siswa yang jujur tersebut. Tindakan yang dianggap sepele oleh siswa namun sangat berdampak besar terhadap sikap dan perilaku saja. Misalnya saja ketika siswa sedang menghadi ujian. Banyak diantara siswa yang ketahuan "mancaliak jimaik atau kunci" pada saat ulangan atau ujian berlangsung. Selain itu banyak juga diantara siswa kami yang keluar masuk we pada saat ujian berlangsung, kami pun selaku pihak sekolah bingung dan muncul pertanyaan besar kenapa hal tersebut terjadi. Setelah diselidiki ternyata di wc sudah tersedia berbagai contekan yang ditulis di dinding wc atau lembaran kertas yang ditulis dengan ukuran tulisan yang sangat sulit untuk dibaca" (Kepsek)

\section{Lebih lanjut YVR mengungkapkan}

"Bahwa banyak diantara siswa di SMA INS Kayu Tanam yang tidak menyerahkan uang SPP tepat pada waktunya, ketika dikonfirmasi kepada orang tua atau wali murid terkait belum dibayarkannya kewajiban tersebut. Laporan dari pihak sekolah menyebabkan banyak orang tua kaget karena menganggap mereka sudah membayarkan kewajiban mereka. Setelah ditindaklanjuti oleh pihak sekolah maka diperoleh informasi bahwa memang merekal peserta didik belum membayarkannya pada pihak sekolah."

\section{Nilai karakter kedisiplinan}

Sangat sulit membangun atau membentuk siswa yang disiplin dalam setiap aktivitas atau kegiatan siswa. Sebagaimana yang kita ketahui bersama bahwasanya kedisiplinan merupakan kunci keberhasilan seseorang. Namun masih ada beberapa diantara siswa di SMA INS Kayu Tanam yang masih belum disiplin. Adapun bentuk sikap yang bertentangan dengan penanaman nilai karakteristik disiplin diantara masih banyak siswa/ siswi yang terlambat datang kesekolah, tidak memakai atribut dengan lengkap yang sesuai dengan yang sudah ditetapkan oleh pihak sekolah,

\begin{abstract}
"Ya memang benar, meskipun pihak sekolah sudah berusaha agar semua peserta didik kami dapat menjalankan disiplin dengan baik. Berbagai upaya sudah dilakukan oleh pihak sekolah agar disiplin dapat dijalankan sebagaiman mestinya seperti dengan membuat peraturan atau tata tertib sekolah dan memajangnya di setiap kelas tapi masih ada beberapa siswa yang melanggarnya. Menetapkan jadwal kedatngan siswa tepat pada pukul 07. 15 wib, akan tapi masih saja ada siswa yang datang terlambat." (Kepsek)
\end{abstract}

Hal senada juga disampaikan oleh Walas Kelas XI yang mangatakan sebagai berikut:

"Kami sudah berusaha agar siswa kami disiplin dengan cara memberikan contoh teladan yang baik, dengan cara dating lebih awal daraipada peserta didik kami. Akan tetapi masih saja ada siswa datang kesekolah dan tetap melanggar aturan yang ada. Misalnya kami, baik kepala sekolah maupun guru harus tiba lebih awal disekolah untuk menyambut siswa yang datang, kami berharap dengan hal itu 
memberikan contoh untuk siswa kami, tapi masih saja ada yang datang terlambat." (JUS)

\section{Nilai karakter peduli lingkungan}

Terkait dengan penanaman nilai karakter peduli lingkungan masih dirasakan kurangnya kepedulian peserta didik untuk menjaga kebersihan, keindahan dan kerapihan lingkungan seperti kelas, wc, taman dan labor.

Faktor-faktor yang Mempengaruhi Pelaksanaan Penanaman Pendidikan Karakter di SMA INS Kayu Tanam

\section{Faktor Pendukung Pelaksanaan Penanaman Pendidikan Karakter di SMA INS Kayu Tanam}

Keberhasilan suatu program sekolah sangat tergantung pada bentuk dukungan dan kerja sama yang terjalin antara pihak sekolah dan pihak lainnya. Berdasarkan hasil temuan penulis dilapangan melalui wawancara yang telah dilakukan, diperoleh informasi bahwasanya keberhasilan pelaksanaan penanaman pendidikan karakter bagi peserta didik yang paling utama adalah tingginya komitmen dari pihak terkait dalam hal ini warga sekolah dan semua komponen yang berada diluar sekolah selain itu kerjasama yang kuat oleh kepala sekolah beserta stakeholders dalam melaksanakan pendidikan karakter di sekolah. hal inisesuai dengan yang sudah diungkapkan oleh pimpinan SMA INS Kayu Tanam:

\begin{abstract}
"Sebuah sekolah tidak akan mampu berkembang dan mampu menghasilkan prestasi tanpa adanya perencanaan yang matang serta didukung oleh tim yang saling mendukung satu sama lainnya. Dalam mewujudkan suatu tujuan maka dibutuhkan kerjasama antar setiap komponen yang ada di sekolah. Sinergi antara komponen yang terdiri atas saya sendiri selaku kepala sekolah, guru, staf pegawai, siswa dan semua warga yang berada dilingkungan sekolah ini.Semuanya harus memiliki komitmen yang tinggi dan saling bekerjasama untuk mewujudkan sekolah yang mampu menanamkan pendidikana karakter dengan baik. Komitmenyang tinggi serta kerjasama tim yang mumpuni merupakan kunci utama dalam mewujudkan pencapaian tujuan sekolah yang mampu menanamkan pendidikan karakter di SMA INS Kayu Tanam." (Wakur)
\end{abstract}

Sebagaimana yang sudah diungkapkan oleh WakilKurikulum selaku pimpinan sekolah menjelaskan bahwa salah satu pendukung dari pelaksanaan penanaman pendidikan karakter di SMA INS Kayu Tanam adalah adanya komitmen yang baik serta kerjasama yang solid antar semua warga yang ada di sekolah. Hal tersebut lebih lanjut juga ditegaskan oleh Walas Kelas XI IS yang mengatakan bahwa:
"Benar sekali, sangat dibutuhkan kerjasama yang solid antara guru dengan orang tua atau wali murid demi terwujudnya sekolah yang mampu menerapkan penanaman pendidikan karakter. Dalam hal ini orang tua siswa atau keluarga merupakan bagian yang mempengaruhi perilaku seorang siswa. Orang merupakan contoh yang utama dalam penerapan pendidikan karakter yang nyata bagi peserta didik. Oleh sebab itu beberapa kegiatan yang dilaksanakan sekolah harus melibatkan orangtua, karena dengan adanya kerjasama dan dukungan dari orangtua siswa dapat membantu kelancaran program yang telah dilaksanakan sekolah dalam membangun karakter siswa." (JUS)

Dari hasil temuan penulis tersebut dapat ditarik suatu kesimpulan, faktor pendukung pelaksanaan penanaman pendidikan karakter di SMA INS Kayu Tanam adalah ialah dibutuhnkannya komitmen yang tinggi serta kerjasama yang solid antara pihak sekolah dengan orang tua atau wali murid peserta didik. Kerjasama tersebut dibutuhkan agar program sekolah dapat terlaksana dengan baik untuk membangun penanaman pendidikan karakter karakter siswa berjalan dengan lancer di SMA INS Kayu Tanam.

\section{Faktor Penghambat}

Selain terdapat faktor pendukung kelancaran program, masih terdapat faktor penghambat sehingga program masih belum berjalan dengan baik. Kepala sekolah menjelaskan faktor penghambat pelaksanaan pendidikan karakter menjelaskan sebagai berikut:

\footnotetext{
"Kalau yang menjadi faktor penghambat menurut saya adalah lingkungan.Letak sekolah yang termasuk semiperkotaan yang banyak dikelilingi tempat hiburan, tempat perbelanjaan dan tempat bermain sehingga mempengaruhi siswa. Selain itu, faktor dana juga mempengaruhi terlaksananya pendidikan karakter, sebab saat ini kami memerlukan dana untuk menyediakan sarana prasarana yang masih kurang seperti untuk membangun gedung perpustakaan, dan mushola. Kami harus menyediakan dana yang tidak sedikit untuk itu." (Kepsek)
}

Berdasarkan wawancara diatas, faktor penghambat pelaksanaan pendidikan karakter adalah lingkungan. Lingkungan secara tidak langsung akan mempengaruhi belajar siswa. Faktor dana juga menjadi penghambat karena dana dibutuhkan untuk menyediakan sarana dan prasarana yang dapat mendukung proses pendidikan karakter.

Selanjutnya berdasarkan keterangan yang disampaikan guru Bid Studiyang mengatakan bahwa:

"Kesadaran peserta didik yang masih kurang juga termasuk faktor penghambat, dikarenakan usia 
sekolah menengah/ remaja yang belum paham akan pentingnya nilai karakter. Pada saat usia seperti ini anak lebih cenderung suka bermain. Selain itu, kurangnya komunikasi antara pihak sekolah dengan orangtua dan kurangnya pengawasan dari pihak sekolah terhadap pergaulan siswa juga merupakan faktor penghambat pelaksanaan pendidikan karakter." (VT)

Berdasarkan pernyataan diatas, yang menjadi faktor penghambat pelaksanaan pendidikan karakter juga berasal dari siswa itu sendiri yang disebabkan oleh faktor usia anak, serta kebijakan dari pihak sekolah selaku lembaga pendidikan.

\section{Pembahasan \\ Pelaksanaan Pendidikan Karakter di SMA INS Kayu Tanam Kabupaten Padang Pariaman}

Berdasarkan hasil temuan penulis dilapangan, penanaman pendidikan karakter di SMA INS Kayu Tanam dilakukan oleh pihak sekolah bersama jajarannya melalui pembiasaan sehari-hari di baik dilingkungan sekolah maupun diluar lingkungan sekolah. Pembiasaan (habituation) dilakukan dengan menjadikan guru atau warga sekolah sebagai contoh atau teladan bagi penanaman nilai karakter bagi siswa. Hal ini senada dengan apa yang diungkapkan oleh Wirdanengsih (2019) yang menyatkan ada beberapa factor yang memberikan pengaruh seseorang dari interaksi social yaitu: 1) Imitasi (meniru), dalam hal ini dampak positif dari meniru mendorong seseorang untuk mematuhi norma dan nilai yang berlaku, 2) Sugesti, yang merupakan anjuran yang dapat melahirkan reaksi langsung tanpa memerlukan pemikiran secara rasional tetapi diterima secara emosional, 3) Identifikasi, merupakan kecenderungan atau keinginan dalam diri seseorang untuk menjadi sama engan pihak lain, 4) Simpati ialah kesenangan seseorang untuk langsung merasakan sesuatu dengan orang lain Sebagai sekolah berasrama yang menuntut para siswanya memiliki keseimbangan antara kecakapan kehidupan duniawi dan kecakapan kehipupan sebagai bekal akhirat. Oleh karena itu selain para siswa memiliki kecerdasan secara intelejensi maka siswa dibekali dengan kemampuan yang dapat menopang kehidupan peserta didik setelah menyelesaikan studi mereka di kampus SMA INS Kayu tanam, diantaranya keterampilan di bidang seni baik seni music, pertunjukan, seni lukis dan seni kriya. Selain itu juga disediakan kompetensi yang lain sesuai dengan minat dan bakat peserta didik berupa keterampilan pertanian, elektronika dan perbengkelan.

Ada beberapa nilai karakter yang yang sangat ditekankan oleh pihak sekolah namun masih belum berjalan sesuai dengan yang diharapkan diantaranya:

1. Nilai karakter religius

2. Nilai karakter disiplin

3. Nilai karakter kejujuran
4. Nilai karakter menghargai prestasi

5. Nilai Peduli lingkungan

6. Nilai karakter peduli social

7. Nilai karakter tanggung jawab.

Faktor-faktor yang Mempengaruhi Penanaman Pendidikan Karakter di SMA INS Katu Tanam Kabupaten Padang Pariaman

\section{Faktor Pendukung}

Beberapa faktor pendukung penanaman pendidikan karakter di SMA INS Kayu Tanam adalah sebagai berikut:

1. Komitmen yang tinggi dalam penanaman pendidikan karakter harus dimilki oleh semua warga sekolah. Dengan adanya komitmen yang tinggi serta tujuan yang sama merupakan kunci utama dalam pencapaian visi dan misi.

2. Kerjasama solid antara semua warga sekolah merupakan kelanjutan dari faktor sebelumnya. Setelah adanya komitmen yang tinggi maka kerjasama yang solid dibutuhkan agar terlaksananya tujuan dari sebuah organisasi. Hal ini sesuai dengan yang diungkapkan oleh Djamarah (2004) yang menyatakan bahwasanya mendidik adalah tanggung jawab orang tua. Kalaupun tugas mendidik akan dilimpahkan kepada guru maka sangat tidak bijak jika beranggapan guru mengambil alih tanggung jawab orang tua secara penuh. Dalam hal ini sangat diperlukan kerjasama yang solid agar penanaman pendidikan karakter dapat terlaksana dengan baik.

3. Dalam mencapai apa yang sudah direncanakan maka keterlibatan orangtua siswa dalam semua kegiatan yang dapat menjunjang penanaman pendidikan karakter, merupakan bagian faktor pendukung yang sangat baik dalam pelaksanaan program-program sekolah. Melalui keterlibatan orang tua siswa sangat membantu pihak sekolah dalam mengawasi siswa selama berada di luar sekolah.

4. Dibutuhkn komunikasi yang baik antar warga sekolah dilakukkan untuk kelancaran program-program dalam rangka mencapai tujuan sekolah . Komunikasi tersebut dilakukan dalam bentuk kegiatan rutin bulanan yang dilakukan oleh kepala sekolah bersama guru dan staf pendidikan lain.

5. Peningkatan fasilitas sebagai sarana dan prasarana penunjang keberhasilan penanaman pendidikan karakter di SMA INS Kayu Tanam. Dengan fasilitas mendukung maka keberhasilan pelaksanaan penanaman pendidikan karakter melalui beberapa fasilitas yang tersedia di lingkungan sekolah. Sejauh ini , pihak sekolah berupaya agar dapat menyediakan fasilitas yang dapat menunjang penanaman pendidikan karakter di SMA INS Kayu Tanam. 
Faktor Penghambat Penanaman Pendidikan Karakter di SMA INS Kayu Tanam

Berdasarkan hasil temuan penulis dilapangan diperoleh beberapa faktor penghambat penanam pendidikan karakter di SMA INS Kayu Tanam sebagai berikut:

1. Masih kurangnya dana sekolah dalam mengembangkan sarana serta prasarana sekolah yang masih kurang seperti masih kurangnya referensi terkait pendidikan karakter di perpustakaan sekolah.

2. Masih kurangnya komunikasi yang intens antara pihak sekolah dengan wali murid karena seringkali dilakukan saat pertemuan dengan orang tua peserta didik seperti rapat rutin bulanan dan tahunan yang ditetapkan oleh pihak sekolah.

3. Dari sisi peserta didik masih kurangnya kesadaran peserta didik dalam penanaman pendidikan karakter. Hal ini dapat dilihat dari masih banyak siswa di SMA INS Kayu Tanam yang menampilkan sikap yang belum sesuai dengan tuntunan pendidikan karakter

4. Karena SMA INS Kayu Tanam merupakan sekolah berasrama maka pihak sekolah sedikit kesulitan mengontrol perilaku dan sikap peserta didik.

\section{SIMPULAN}

Berdasarkan temuan penulis dilapangan dapat disimpulkan beberapa hal sebagai berikut:

1. Penanaman pendidikan karakter di SMA INS Kayu Tanam dilakukan melalui pembiasaan sehari-hari di sekolah. Nilai karakter yang dilaksanakan di SMA INS Kayu Tanam yang masih perlu menjadi perhatian sekolah antara lain Karakter religius, karakter disiplin, karakter kejujuran,karakter peduli lingkungan.

2. Terdapat dua factor yang mempengaruhi pelaksanaan pendidikan karakter di SMA INS Kayu Tanam yaitu: dikatakan sebagai faktor pendukung pelaksanaan pendidikan karakter di SMA INS Kayu Tanam yaitu:a) Komitmen yang tinggi semua pihak sekolah dan orang tua murid b) Kerjasama yang solid dari semua pihak c) Keterlibatan dari semua unsure sekolah, d) pengembangan sarana pendukung sekolah, Faktor penghambat pelaksanaan pendidikan karakter di SMA INS Kayu Tanam adalah:a) Masih kurangnya dana dalam mengembangkan sarana dan prasarana, b) Masih kurangnya komunikasi yang intens anatara pihak sekolah dengan orang tua/ wali murid c) Masih kurangnya kesadaran siswa dalam penanaman pendidikan karakter.

\section{DAFTAR PUSTAKA}

J, Lexy Moleong. 2010. Metodologi Penelitian Kualitatif. Bandung: Remaja Rosdakarya.

Kementerian Pendidikan Nasional Badan Penelitian dan Pengembangan Pusat Kurikulum dan Perbukuan. 2011. Panduan Pelaksanaan Pendidikan
Karakter. Jakarta: Pusat Kurikulum dan Perbukuan. Di Download pada 22 Juni 2021. http://repository.unand.ac.id/22742/1/4_PANDUA N_PELAKS_PENDIDIKAN_KARAKTER.pdf

Marzuki. 2012. Jurnal: Pengintegrasian Pendidikan Karakter dalam Pembelajaran di Sekolah. Yogyakarta: FIS Universitas Negeri Yogyakarta.

Syaiful Bahri Djamarah. 2004. Pola Komunikasi (Orang Tua dan Anak Dalam Keluarga).Jakarta: Rineka Cipta

Wirdanengsih.2019. Anak dalam Perspektif Sosial Budaya.Kediri: Fam Publishing 